were elected officers of the Society: Honorary President, Mr. G. Sykes; Honorary Secretary, Dr. Ella M. Barnes; Honorary Treasurer, Mr. G. Elis Jones; Honorary Editors, Dr. S. E. Jacobs and Dr. D. J. Jayne-Williams; Honorary Publications Manager, Mr. A. H. Walters; Honorary Advertising Manager, Mr. E. J. Mann; Members of Committee, Mr. B. M. Gibbs, Dr. N. D. Harris, Dr. Agnes A. Nichols, Dr. J. R. Norris, Dr. A. M. Paton, Dr. Patricia M. Scholes, Dr. A. Seaman, Dr. Joan Taylor, Dr. G. C. Ware.

\section{Australian Mammal Society}

THE following officers and council members were elected for 1961-62 at the third general meeting of the Australian Mammal Society, held in Brisbane, Australia, on May 26: President, Dr. G. B. Sharman; Vice-President, Dr. W. D. L. Ride; Secretary, Dr. R. G. Chittleborough; Treasurer, Mr. J. A. Thomson; Editor, Mr. J. H. Calaby; Council Members, Dr. A. K. Lee and Dr. A. G. Lyne.

\section{The Night Sky in September}

New moon occurs on Sept. 10d. 02h. 50m. U.T. and full moon on Sept. 24d. 11h. 34m. The following conjunctions with the Moon take place: Sept. ld. 23h., Aldebaran 0.3 ${ }^{\circ}$ S.; Sept. 7 d. 00 h., Venus $2^{\circ}$ N.; Sept. 19d. 22h., Saturn $3^{\circ}$ S.; Sept. 20h. 05m., Jupiter $3^{\circ} \mathrm{S}$.; Sept. $29 \mathrm{~d} .07 \mathrm{~h}$. , Aldebaran $0 \cdot 4^{\circ} \mathrm{S}$. In addition to these conjunctions with the Moon, Mars is in conjunction with Spica on Sept. 20d. 11h., Mars being $2^{\circ} \mathrm{S}$., Mercury with Spica on Sept. 2ld. 12h., Mercury being $0 \cdot 1^{\circ} \mathrm{N}$., Mercury with Mars on Sept. 22d. 21h., Mercury being $3^{\circ} \mathrm{S}$., and Venus with Regulus on Sept. 22d. 23h., Venus being $0 \cdot 4^{\circ} \mathrm{N}$. Mercury is too close to the Sun for observation. Venus is a morning star, rising at $1 \mathrm{~h} .50 \mathrm{~m}$., $2 \mathrm{~h} .30 \mathrm{~m}$. and $3 \mathrm{~h} .10 \mathrm{~m}$. on September 1,15 and 30 , respectively. Its stellar magnitude on September 15 is -3.4 ; the visible portion of the apparent disk increases during the month from 0.792 to 0.870 and its distance from the Earth increases from 115 to 131 million miles. Mars is too close to the Sun for observation. Jupiter is an evening star, setting at $1 \mathrm{~h} .30 \mathrm{~m} ., 0 \mathrm{~h} .30 \mathrm{~m}$. and $23 \mathrm{~h} .30 \mathrm{~m}$. on Sept. 1,15 and 30 , respectively. It is in Capricornus; its stellar magnitude on Sept. 15 is $-2 \cdot 2$, and its distance from the Earth is 410 million miles. Saturn is an evening star, setting at 1h. $10 \mathrm{~m}$., $0 \mathrm{~h} .10 \mathrm{~m}$. and $23 \mathrm{~h} .10 \mathrm{~m}$. at the beginning, middle and end of the month, respectively. It is in Sagittarius; its stellar magnitude is +0.6 on Sept. 15 and its distance from the Earth is 880 million miles. Occultations of stars brighter than magnitude 6 are as follows, observations being made at Greenwich: Sept. 1d. 23h. $46 \cdot 7 \mathrm{~m} ., \sigma^{2}$ Tau. $(R)$; Sept. 16d. 19h. $54 \cdot 7 \mathrm{~m} ., 24$ Sco. $(D)$; Sept. 26d. 21h. 25.6m., $\xi^{2}$ Cet. $(D)$; Sept. 26d. 22h. 19.6m., $\xi^{2}$ Cet. $(R)$; Sept. 28d. 1h. 40.4m., 5 Tau. $(D)$; Sept. 28d. 2h. $46 \cdot 6 \mathrm{~m} ., 5$ Tau. $(R)$; Sept. 28 d. 22h. 50.1m., $\gamma$ Tau. $(D)$; Sept. 28d. 23h. 43.0m., $\gamma$ Tau. $(R)$; Sept. 29d. 3h. 32.9m., $\theta^{1}$ Tau. $(D)$; Sept. 29 d. 3 h. $45 \cdot 1 \mathrm{~m}$., $\theta^{2}$ Tau. $(D)$; Sept. 29d. 4h. 30.6m., $\theta^{2}$ Tau. $(R)$; Sept. 29 d. 4h. $43 \cdot 2 \mathrm{~m} ., \theta^{1}$ Tau. $(R)$; Sept. 29 d. 7h. 57.7m., $\alpha$ Tau. $(D)$; Sept. 29 d. 8 h. $53.8 \mathrm{~m}$., $\propto$ Tau. $(R) . \quad D$ and $R$ refer to disappearance and reappearance, respectively. The autumnal equinox occurs on Sept. 23d. 07h.

\section{Announcements}

Dr. L. R. G. Treloar, of the Shirley Institute, Manchester, has been awarded the Colwyn Medal of the Institution of the Rubber Industry. Mr. M. M.
Heywood, director of P. D. Cow and Co., Ltd., has been awarded the Institution's Hancock Medal.

A symposrum on "Forest Ecosystem" (definitions and classification of forest ecosystem) was held in Montreal in 1959 under the auspices of the Ninth International Botanical Congress. Dr. I. Hustich of Finland was chairman and organizer for the symposium. The papers have now been published in full in a special issue of the Bulletin of the International Society for Tropical Ecology. Copies can be had from Dr. G. S. Puri, General Secretary, International Society for Tropical Ecology, 10-Chatham Lines, Allahabad, India (price Rs. 25, $£ 2,6.00$ dollars).

THe Chemical Society is arranging a symposium on electron spin resonance, which will be held in Queen Mary College, London, on November 2. Further information can be obtained from the Secretary, Chemical Society, Burlington House, London, W.1.

The annual Pittsburgh Diffraction Conference will be held at the Mellon Institute, Pittsburgh, Pennsylvania, during November 1-3. Further information can be obtained from T. B. Massalski, Mellon Institute, 4400 Fifth Avenue, Pittsburgh 13, Pennsylvania.

The Universities Federation for Animal Welfare (UFAW) will hold its annual Summer Congress at Shipham, Winscombe, Somerset, during September 16-23, 1961. Further information can be obtained from UFAW (Summer Congress), 7a Lamb's Conduit Passage, London, W.C.1.

THE Borough Polytechnic, London, is organizing a course of six lectures on "The Technique of Technical Writing". The lectures will be given on Friday afternoons commencing October 20. Further information can be obtained from the Secretary, Borough Polytechnic, Borough Road, London, S.E.1.

A MEETING of the British Pharmaceutical Conference will be held at Portsmouth during September 18-22. To be included in the programme is a lecture by Dr. A. Isaacs on "Interferon" and a symposium on "Skin Medication". Further information can be obtained from the secretary, British Pharmaceutical Conference, 17 Bloomsbury Square, London, W.C.1.

The Food Group of the Society of Chemical Industry is organizing a symposium on "Recent Advances in Processing Cereals" at the Royal Society of Medicine, London, during September 14-15. Further information can be obtained from the Assistant Secretary, Society of Chemical Industry, 14 Belgrave Square, London, S.W.I.

AN international symposium on "Photoelasticity" will be held at the Illinois Institute of Technology, Chicago, Illinois, during October 29-31. The symposium will consist of five sessions including: birefringent coatings; photothermoelasticity and photoplasticity; two- and three-dimensional photoelasticity; dynamic photoelasticity and three-dimensional photoelasticity. Further information can be obtained from Prof. M. M. Frocht, chairman of the International Symposium on Photoelasticity, Department of Mechanics, Illinois Instituts of Technology, Technology Center, Chicago, 16.

Erratum. In the communication entitled "Effects of Injections of Some Intermediary Metabolites on the 'Insulin Response' of Normal Rabbits", which appeared in the issue of July 29 , p. 491, for "trichloroacetic" on line 9 read "tricarboxylic". 